\title{
Phosphorus retention and release from sandy soils of the Peel-Harvey catchment
}

\author{
G.S.P. Ritchie \& D.M. Weaver
}

\begin{abstract}
In order to manage phosphorus (P) losses from soils to waterbodies, knowledge of the mechanisms through which $\mathrm{P}$ is retained or released from the soil is essential. Sandy soils of the Peel-Harvey catchment (Western Australia) were subjected to a range of environmental and management factors in the laboratory and field in order to gain an understanding of the mechanisms that affect the magnitude of $\mathrm{P}$ losses. Sandy soils accumulated $\mathrm{P}$, despite having little sorption capacity, and this accumulation could be monitored by measuring an acid-extractable fraction. The potential, short-term $\mathrm{P}$ loss could be estimated by determination of water-soluble soil solution $P$ prior to winter rains. An annual cycle of the change in arbitrarily defined soil-P pools is discussed in relation to environmental and management factors. Laboratory experiments indicated that $P$ rundown and potential annual $P$ loss in the absence of $\mathrm{P}$ fertilizers could be estimated using bicarbonate extractable P. Phosphorus losses were decreased by the application of fertilizers with a low content of water-soluble P. The low ability of sandy soils of the Peel-Harvey coastal catchment to retain P, when compared to other Western Australian soils, is because of low contents of clay minerals and iron and aluminium hydrous oxides.
\end{abstract}

\section{Introduction}

Understanding the behaviour of phosphorus (P) in soils is a prerequisite for selecting effective management proposals for controlling $\mathrm{P}$ losses. Initially we need to know the forms of $\mathrm{P}$ that already exist and their leachability. When new management practices are introduced (such as use of less-soluble $P$ fertilizer), we then need to assess the short and long-term changes in $P$ storage from regular applications of new fertilizers and the effect this has on losses.

Phosphorus is lost to drainage from soils used for agriculture by release from the accumulated soil store $(70-85 \%$ of the total loss on old pastured land) and direct loss from fertilizer applied in the current year. The total $\mathrm{P}$ store in soils varies according to capacity to bind $\mathrm{P}$ and fertilizer history. Even on highly-leaching sands, $P$ accumulates, predominantly in the surface soil (as organic $\mathrm{P}$ or as inorganic compounds) from past applications of superphosphate.

Phosphorus losses from sandy soils in the PeelHarvey Catchment area are a major source of the $\mathrm{P}$ which causes algal blooms in the inlet and estuary [5]. However, the effect of soil properties, environmental conditions and management practices on the extent of $\mathbf{P}$ losses is not as fully understood. These are important aspects in determining whether leaching losses can be decreased sufficiently to meet catchment target $\mathrm{P}$ losses $\left(<0.375 \mathrm{~kg} \mathrm{Pha}^{-1} \mathrm{y}^{-1}\right.$ from the coastal portion of the catchment) and still maintain plant production. 


\section{Soils and climate of the Peel-Harvey catchment}

The combination of soils, landscape and climate in the Peel-Harvey catchment have resulted in an ecosystem that is extremely susceptible to the accumulation of soluble substances within the Peel-Harvey estuary and associated waterways. The region has a mediterranean climate of hot, dry summers and cool, wet winters. Eighty-five percent of the annual rainfall of $1000 \mathrm{~mm}$ falls between May and October.

The soils of the Peel-Harvey catchment have been divided into four broad groups according to their potential ability to leach phosphorus (Table 1, Fig. 1). Ninety percent of the $P$ exported from the catchment has been estimated to come from the deep grey sands and sand-over-clay soils which comprise $70 \%$ of the coastal catchment area [2]. Total P lost from the deep grey sands has been found to be four times that of the sand-overclays and six times that of heavier soils [5].

The deep grey sands of the catchment are naturally low in total $\mathrm{P}\left(<30 \mu \mathrm{g} \mathrm{g}^{-1}\right)$, of which approximately $75 \%$ is organic $P$, and the soils have a very low capacity to sorb $P$. The low sorption capacity is due to low contents of clay and iron and aluminium hydrous oxides (Table 1).

The sandy, aeolian soils originate from weathered materials of old lateritic soils to the east of the Darling Scarp as well as marine deposits, and their naturally low content of plant nutrients and other ions has been depleted even further by leaching. Their organic matter content is generally low but depends on topographic position ( $<2 \%$ on dunes and $<5 \%$ on swales) in a landscape of very low relief (the majority of slopes are $<1 \%$ ). Hence, the soils have low cation exchange capacity $\left(\sim 2 \mathrm{cmol} \mathrm{kg}^{-1}\right)$, acidic $\mathrm{pH}$ values ( $\leqslant 5.0$ in $0.01 \mathrm{M} \mathrm{CaCl}_{2}$ ), low water holding capacity $(\approx 10 \%$ moisture at field capacity) and high hydraulic conductivities in the topsoil. The low ability of these soils to sorb P, and their efficient drainage, has resulted in a large input of $\mathrm{P}$ into the Peel-Harvey estuary during the winter period of high rainfall.

Table 1. Typical range of properties of soils the coastal catchment of the Peel-Harvey estuary compared with other Western Australian soils

\begin{tabular}{|c|c|c|c|c|c|c|c|}
\hline \multirow[t]{2}{*}{ Location } & \multirow[t]{2}{*}{ Soil Type } & \multirow{2}{*}{$\begin{array}{l}\text { P sorption } \\
\text { classification }^{1}\end{array}$} & \multirow[t]{2}{*}{$\mathrm{PRI}^{2}$} & \multirow{2}{*}{$\begin{array}{l}\text { Total P } \\
(\mu \mathrm{gg}-1)\end{array}$} & \multirow[t]{2}{*}{$\mathrm{Fe}$} & \multirow{2}{*}{\multicolumn{2}{|c|}{$\mathrm{Al}$}} \\
\hline & & & & & & & \\
\hline \multirow[t]{4}{*}{ Peel-Harvey } & $\begin{array}{l}\text { Deep grey } \\
\text { sands }\end{array}$ & $\begin{array}{l}\text { very weakly } \\
\text { sorbing or } \\
\text { desorbing }\end{array}$ & $-1-2$ & $20-80$ & $0.002-0.05$ & $0.003-0.05$ & $0.5-2.0$ \\
\hline & $\begin{array}{l}\text { Sands-over- } \\
\text { clays }\end{array}$ & weakly sorbing & $2-5$ & $65-200$ & $0.01-0.12$ & $0.01-0.06$ & $1.5-4.0$ \\
\hline & $\begin{array}{l}\text { Brown and } \\
\text { yellow sands }\end{array}$ & $\begin{array}{l}\text { moderately } \\
\text { sorbing }\end{array}$ & $5-20$ & $100-300$ & $0.10-0.20$ & $0.10-0.15$ & $1.5-4.0$ \\
\hline & $\begin{array}{l}\text { Loams, clays } \\
\text { and peats }\end{array}$ & $\begin{array}{l}\text { strongly } \\
\text { sorbingh }\end{array}$ & $20-150$ & $150-700$ & $1.0-2.0$ & $0.4-0.8$ & $5.0-25.0$ \\
\hline $\begin{array}{l}\text { Darling } \\
\text { Scrap }\end{array}$ & $\begin{array}{l}\text { Lateritic } \\
\text { gravels }\end{array}$ & $\begin{array}{l}\text { strongly } \\
\text { sorbing }\end{array}$ & $50-200$ & $150-800$ & $1.5-2.5$ & $0.6-1.0$ & $10.0-35.0$ \\
\hline $\begin{array}{l}\text { Eastern } \\
\text { wheatbelt }\end{array}$ & $\begin{array}{l}\text { Clays and } \\
\text { loams }\end{array}$ & $\begin{array}{l}\text { very strongly } \\
\text { sorbing }\end{array}$ & $150-800$ & $150-800$ & $1.5-3.0$ & $0.8-1.2$ & $10.0-35.0$ \\
\hline South Coast & Red loam & $\begin{array}{l}\text { very strongly } \\
\text { sorbing }\end{array}$ & $>1000$ & $150-1500$ & $2.5-4.0$ & $1.0-2.0$ & $10.0-35.0$ \\
\hline
\end{tabular}

${ }^{1}$ Classification scheme of Allen and Jeffery (1990).

${ }^{2}$ PRI (Phosphorus Retention Index), a single-point $\mathrm{P}$ sorption measure, is defined as the ratio:

$$
\frac{P_{\mathrm{ads}}\left(\mu \mathrm{gg}^{-1} \text { soil }\right)}{P_{\mathrm{eq}}\left(\mu \mathrm{g} \mathrm{P} \mathrm{mL}^{-1}\right)}
$$

resulting from equilibrating soil with a $10 \mu \mathrm{g} \mathrm{P} \mathrm{mL}{ }^{-1}$ solution $\left(1 \mathrm{~g}\right.$ soil in $20 \mathrm{~mL}$ solution) for $16 \mathrm{~h}$ at $23^{\circ} \mathrm{C}$, where $P_{\text {ads }}$ is the amount of $\mathrm{P}$ adsorbed and $P_{\mathrm{eq}}$ is the equilibrium $\mathrm{P}$ concentration. 


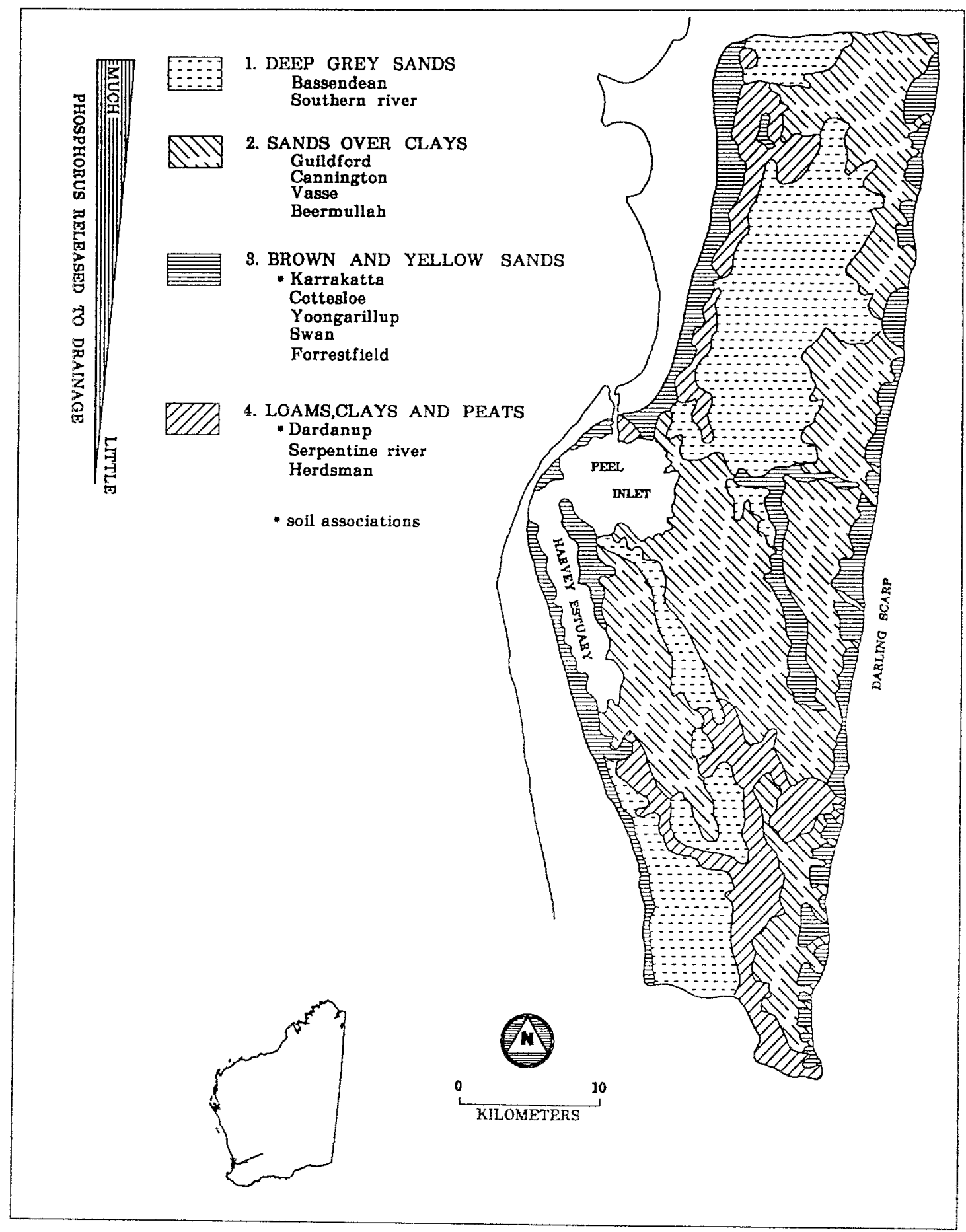

Fig. 1. Distribution of major soil groups on the coastal plain catchment of the Peel-Harvey estuarine system and their relative phosphorus leaching potential (After [5].) 


\section{Phosphorus reactions in soils}

When $\mathrm{P}$ enters the soil, a variety of reactions can occur. The four main $\mathrm{P}$ pools in Fig. 2 may be subdivided into fast and slow cycling sections and the $\mathrm{P}$ may either be in the organic or inorganic form.

Individually, each pool may be described by its capacity (size), affinity (strength of binding P) and flux (rate of movement to and from the pool). The properties of each pool will depend upon the presence of different types of soil constituents, e.g. iron and aluminium oxides, organic matter, clay minerals. The amount of each type determines the capacity, whereas each consituent will have a different affinity and flux to or from other pools. The capacity and affinity of iron and alumium oxides, organic matter and clay minerals for $\mathrm{P}$ sorption comes about because of the high surface area and charged surface. Phosphorus sorption by the deep grey sands and sand-over-clay soils is severely limited because the amount of constituents that contribute to both capacity and affinity is also limited (Table 1). Other Western Australian soils naturally have low fertility but do not have such limited capacity (e.g. some soils of the Darling Scarp, Eastern

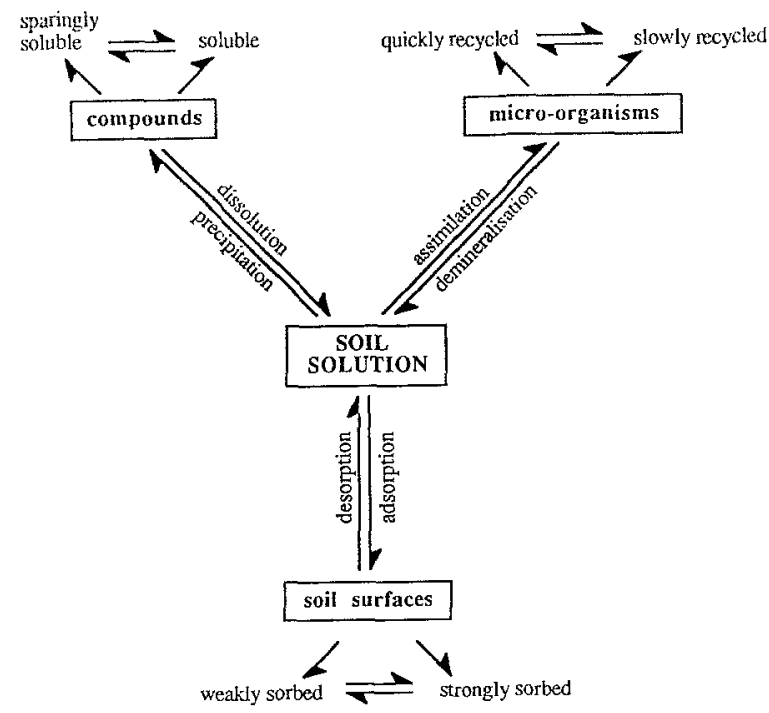

Fig. 2. Soil phosphorus pools and mechanisms of transport between the pools. wheatbelt and South Coast; Table 1) because they contain much larger quantities of clay and iron and aluminium hydrous oxides (e.g. goethite, haematite, gibbsite and boehmite).

Collectively, the major property to consider is the equilibrium between the pools. The forms of $P$ in the soil do not exist as measurable entities since there is continual movement of $P$ from one pool to another. If there are no inputs or outputs from the system, the cycling between pools reaches a quasi-equilibrium. Inputs will favour an equilibrium shift towards the solid phases whereas outputs shift the equilibrium towards the liquid phase.

In the Peel-Harvey catchment area there are regions of sandy soils where the equilibrium is continually being driven to the liquid phase by the loss of $\mathrm{P}$ by leaching.

\section{Phosphorus retention}

Regular applications of ordinary superphosphate to sandy soils in laboratory leaching experiments led to a build up of acid extractable (0.1M $\mathrm{H}_{2} \mathrm{SO}_{4}$ ) inorganic $\mathrm{P}$ (Fig. 3) even though more than $80 \%$ of $\mathrm{P}$ in the fertilizer was lost during the leaching phase following application. Changing the fertilizer to a less P-soluble form (coastal

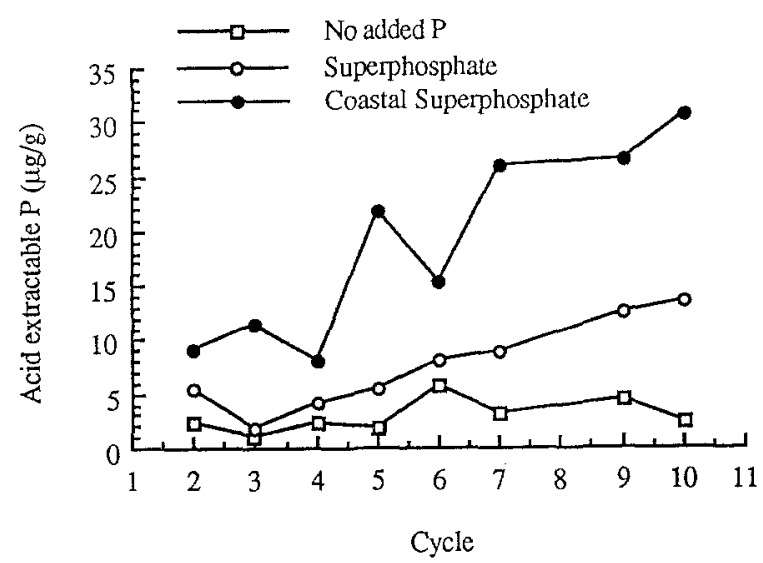

Fig. 3. Acid extractable $\mathrm{P}\left(\mu \mathrm{g} \mathrm{g}^{-1}\right)$ for a grey acid sandy soil continuously unfertilized $(\square)$ or continuously fertilized with superphosphate $(O)$ or coastal superphosphate $(\bullet)$ at $20 \mathrm{~kg}$ $\mathbf{P h a}{ }^{-1}$ (After [9]). 
superphosphate - a granulated mixture of equal parts of superphosphate, rock phosphate and elemental sulphur; [10]) did not change the major inorganic form of $\mathrm{P}$ in the soil but significantly increased the amount retained (Fig. 3; [7]).

\section{Phosphorus release}

The potential loss of $\mathrm{P}$ depends on the amount of $\mathrm{P}$ which may be rapidly released into the soil solution. The forms of $\mathrm{P}$ in soils were arbitrarily divided into two pools which differed in their ability to release $\mathrm{P}$ into the soil solution quickly [8]:

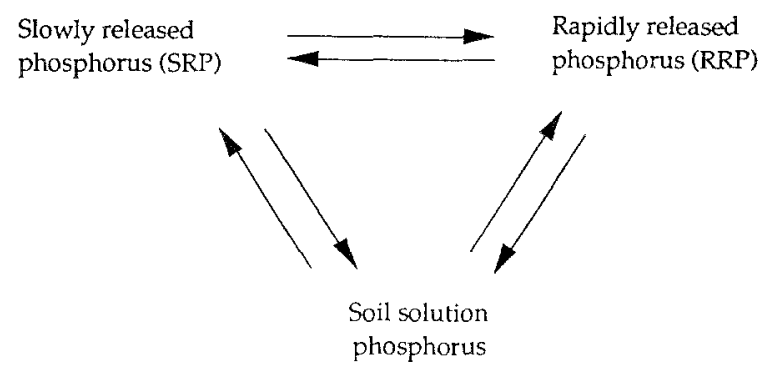

The concentrations of $\mathrm{P}$ in these pools is constantly changing in response to inputs from fertilizers and plant death and to outputs by drainage and plant uptake.

\section{Short term losses}

Phosphorus release during a single growing season depends upon soil type, environmental conditions and previous as well as current management practices (Table 2) [6]. A possible annual cycle for $P$ losses from sandy soils in a mediterranean climate was postulated from lab- oratory and field experiments in the Peel-Harvey catchment (Fig. 4) [8].

The loss of $\mathrm{P}$ was greatest at the beginning of the wet season and was governed mainly by the solubility of the recently-applied fertilizer, the extent of sorption and the weather pattern. At

(a) Beginning of winter

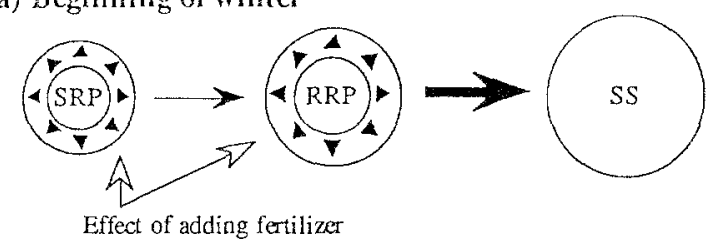

(b) After leaching/runoff commences

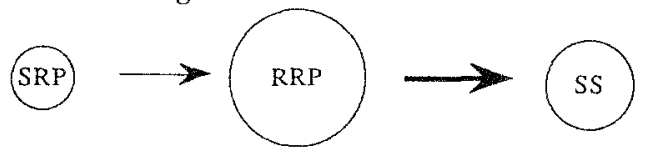

(c) After a pause in rainfall
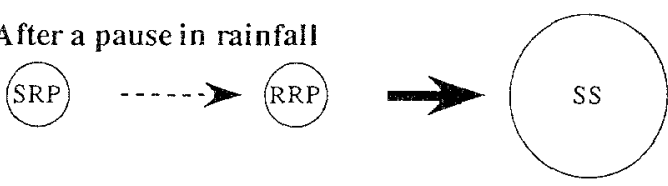

(d) End of winter

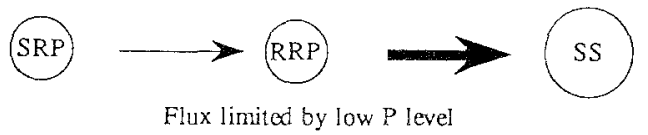

(e) During summer

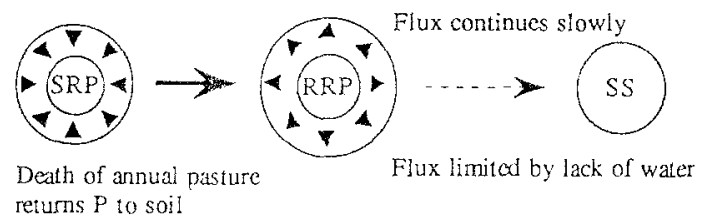

Fig. 4. Schematic representation of seasonal changes of slowly released $\mathrm{P}$ (SRP), rapidly released $\mathrm{P}$ (RRP) and soil solution P (SS) (After [8]). The repeating cycle of annual events is (a), (b), (c), (d), (e).

Table 2. Some factors affecting phosphorus losses from soils

\begin{tabular}{lll}
\hline Soil & Environmental & Management \\
\hline Hydrous oxides & Rainfall & Fertilizer type \\
Organic matter & Storm interval & Fertilizer application rate \\
Clay fraction & Flooding & Fertilizer application method \\
P content & Temperature & Plant growth \\
Soil solution properties & Drainage & \\
Non-wetting properties & & \\
\hline
\end{tabular}


the beginning of winter, there is a large amount of $\mathrm{P}$ in the soil solution after the initial rains have wet the soil ((a) in Fig. 4). As the season progresses, further rain depletes $P$ in the soil solution by drainage ((b) in Fig. 4). This disturbs the equilibrium between the pools and so rapidly-released $\mathbf{P}$ moves from the soil solution to balance the loss. The rate of release of $P$ to the soil solution was slower than the rate of $P$ removal by drainage and hence the amount of $\mathrm{P}$ lost decreases as rainfall continues. However, intervals between rainstorms can increase the $P$ released when rain starts again because $P$ continues to move into solution during the pause, even though excess drainage has temporarily ceased ((c) in Fig. 4). At the end of winter, the soil solution and the pool of rapidly-released $P$ are both depleted by prolonged losses to drainage and plant uptake ((d) in Fig. 4). During summer the concentration of $\mathrm{P}$ in the rapidlyreleased pool increased presumably due to replenishment from slowly released sources. The rate and extent of replenishment was increased by occasional summer storms that wet the soil but not sufficiently to cause leaching. The death and decomposition of annual pasture late in spring, and the application of $\mathrm{P}$ fertilizers late in autumn, also replenish the slowly and rapidlyreleased pools which will release $\mathrm{P}$ into the soil solution once the rains of the next season begin.

The extent of $\mathbf{P}$ losses will also be influenced by the mechanism of water transport [8]. Vertical leaching and lateral flow at depth in the soil increase the opportunity for $\mathrm{P}$ uptake by deeprooted plants and $\mathrm{P}$ sorption by soil substrates and hence can decrease losses. On the other hand, runoff and lateral flow in the upper few centimetres of the soil tend to restrict $\mathrm{P}$ from broadcast fertilizer to the topsoil and decrease its contact with soil and plant roots and hence may increase $\mathrm{P}$ losses.

\section{Long term losses}

Long term losses ( $>1$ year) are mainly governed by the type, amount and method of application of $P$ fertilizers within the constraints of the prevailing environmental conditions and management practices. In laboratory experiments conducted to study long term $\mathrm{P}$ losses, deep grey sands were subjected to ten consecutive cycles designed to simulate the mediterranean climate in the catchment [9]. Each cycle consisted of a wet phase, during which the equivalent of $850 \mathrm{~mm}$ of rainfall was leached through soil, and a drier phase, during which soil was incubated in the presence of moisture equivalent to summer rainfall $(150 \mathrm{~mm})$.

In laboratory leaching experiments, $\mathrm{P}$ losses from two deep grey sands (one high $\mathrm{P}$ and one low $\mathrm{P}$ with 26 and $11 \mu \mathrm{g} \mathrm{g}^{-1}$ bicarbonate- extractable $P$, respectively) previously fertilized with superphosphate were found to decrease exponentially once fertilization ceased (Fig. 5). This showed the low affinity and $\mathrm{P}$ sorption capacity of the soil and also that $\mathrm{P}$ was stored mainly in a form that could be rapidly released [9].

The shape of the curves in Fig. 5 suggested that one curve may be used to represent the decline in $\mathrm{P}$ lost with time because the curve for the lower $\mathrm{P}$ soil appears to be an extension of the curve for the soil containing more $P$. One curve was also adequate to explain water soluble $P$ concentrations in sandy soils during winter [6].

In laboratory leaching experiments on two deep grey sands the amount of bicarbonate extractable $\mathrm{P}$ [3] at the end of the dry phase (i.e. summer) was linearly related to the amount of $P$ lost in the following wet phase (Fig. 6; [9]), provided that no $\mathrm{P}$ was applied. Therefore, bicarbonate-extractable $\mathrm{P}$ measured at the end of

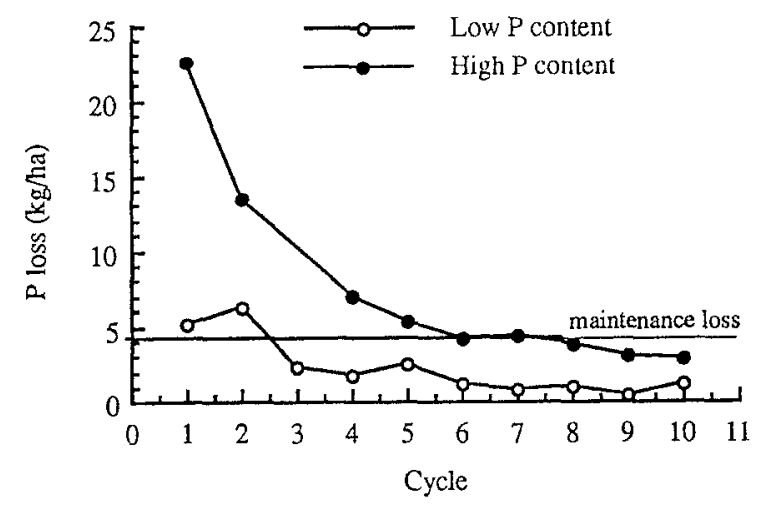

Fig. 5. Change in $\mathrm{P}$ loss $\left(\mathrm{kg} \mathrm{ha}^{-1}\right)$ since fertilization ceased with increasing number of leaching cycles for acid grey sandy soils with low $(\mathrm{O})$ or high $(\bullet)$ bicarbonate-extractable $\mathrm{P}$ (After [9]). 


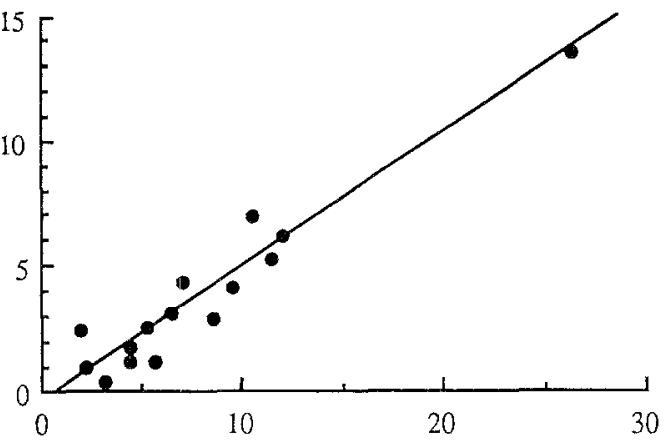

Summer soil test (bicarbonate extractable $\mathrm{P} \mu \mathrm{g} / \mathrm{g}$ )

Fig. 6. Laboratory estimation of the leaching loss of $P$ $\left(\mathrm{kg} \mathrm{ha}^{-1}\right)$ from acid grey sandy soils as a function of the bicarbonate extractable $\mathrm{P}\left(\mu \mathrm{gg}^{-1}\right)$ measured in the soil test prior to leaching (After [9]).

summer could be used to estimate the amount of $P$ that would be lost in the following year if no $P$ was applied. Having established the soil's current ability to lose P, Fig. 5 may then be used to estimate how long it would take to run down the $P$ in that soil to the minimum concentration required for pasture growth (i.e. maintenance requirements) if the levels were originally more than adequate. Examples of estimates of rundown times are given in Table 3 for deep grey sands containing different initial levels of bicarbonate-extractable P. An extensive survey indicated that approximately $60 \%$ of deep grey sands in the catchment had bicarbonate-extractable $\mathrm{P}$ concentrations above the minimum required for pasture growth (8 $\mathrm{gg} \mathrm{g}^{-1}$; Table 3) [4].

The annual $\mathrm{P}$ loss associated with the minimum bicarbonate extractable $\mathrm{P}$ concentration when two deep grey sands were leached in the laboratory was approximately $4 \mathrm{~kg} \mathrm{Pha}^{-1}$. The $\mathrm{P}$ loss in laboratory leaching experiments would be higher than that observed in the field because of the absence of plants, the absence of soil substrates capable of sorbing $P$, and differences between leaching regimes in the laboratory and field.

When sandy soils were fertilized during ten laboratory leaching cycles with superphosphate or the less soluble coastal superphosphate [10], there was an increase in the amount of P lost by leaching, but between 10 and $40 \%$ more $P$ was leached by adding superphosphate rather than coastal superphosphate when compared at equivalent rates [9]. Phosphorus losses from coastal superphosphate increased with successive applications as the number of leaching cycles increased, but were never greater than $\mathrm{P}$ losses from superphosphate (Fig. 7).

In the very long term (tens to hundreds of

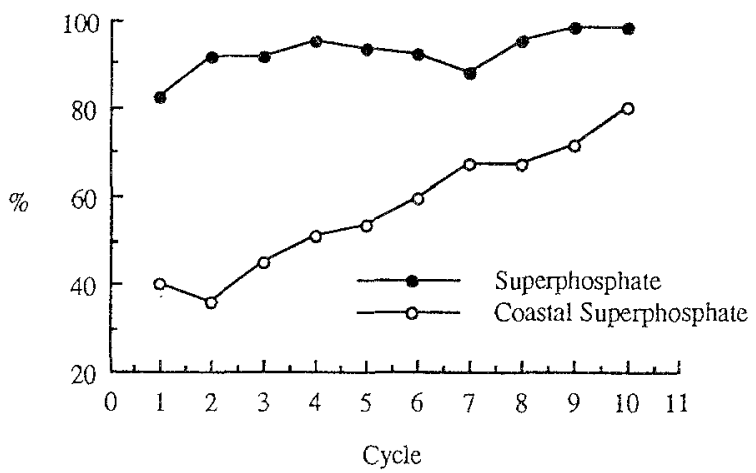

Fig. 7. Cumulative fertilizer $\mathrm{P}$ lost as a percentage of the cumulative fertilizer $\mathbf{P}$ added continuously at $10 \mathrm{~kg} \mathrm{Pha}^{-1}$ as superphosphate $(\bullet)$ or coastal superphosphate $(\mathrm{O})$. (Modified from [9].)

Table 3. Phosphorus losses and run-down times from deep grey sands with varying levels of bicarbonate extractable $\mathrm{P}$

\begin{tabular}{|c|c|c|c|c|c|}
\hline \multirow{2}{*}{$\begin{array}{l}\text { Bicarbonate } \\
\text { extractable } \mathrm{P} \\
\left(\mu \mathrm{gg}^{-1}\right)\end{array}$} & \multirow{2}{*}{$\begin{array}{l}\text { Associated } \\
\text { loss } \\
\left(\mathrm{kg} \mathrm{ha}^{-1}\right)\end{array}$} & \multirow{2}{*}{$\begin{array}{l}\text { Minimum run-down } \\
\text { time to maintenance } \\
\text { levels }^{2}\end{array}$} & \multirow[t]{2}{*}{$\begin{array}{l}\text { \% reduction in } \\
\mathrm{P} \text { loss }\end{array}$} & \multicolumn{2}{|c|}{$\begin{array}{l}\text { Minimum run-down time to achieve } \\
\text { (years) }\end{array}$} \\
\hline & & & & $\begin{array}{l}50 \% \\
\text { reduction }\end{array}$ & $\begin{array}{l}\text { annual loss } \\
2 \mathrm{~kg} \mathrm{ha}^{-1}\end{array}$ \\
\hline $8-12$ & $4-6$ & $0-2$ & $0-30$ & $>4$ & $>4$ \\
\hline $12-16$ & $6-8$ & $2-3.5$ & $30-45$ & $3-4$ & $5-6$ \\
\hline $16-20$ & $8-11$ & $3.5-4$ & $45-65$ & -3 & $6-8$ \\
\hline $20-24$ & $11-13.5$ & $4-5$ & $65-70$ & -3 & $>8$ \\
\hline $24-28$ & $13.5-16.5$ & $5-5.5$ & $70-75$ & -3 & $>8$ \\
\hline
\end{tabular}

${ }^{1}$ Phosphorus lost in a following wet season of $850 \mathrm{~mm}$ continuous rain in the absence of plants.

${ }^{2}$ Maintenance level is $8 \mu \mathrm{gg}^{-1}$ bicarbonate extractable $\mathrm{P}$. 
years), soils other than deep grey sands and sand-over-clay soils may become more significant contributors to $\mathrm{P}$ export. The deep grey sands and sand-over-clay soils have probably reached a steady state in terms of inputs and outputs because of their inherent limited $\mathrm{P}$ sorption capacity. In loam and clay soils the equilibrium is probably still driven to the solid phase, but as fertilization continues, the pool that provides capacity and affinity for $\mathrm{P}$ sorption will diminish and the equilibrium will shift (Fig. 1) to favour the liquid phase.

\section{Conclusions}

The work outlined in this review has enabled us to ascertain the natural forms of $\mathbf{P}$ in deep grey sands of the Peel-Harvey catchment, their associated soil properties, and the cycle of $P$ in them under a mediterranean environment. From this, and previously published work, we conclude that:

1. Sands and sand-over-clay soils of the PeelHarvey coastal catchment are naturally infertile and have very limited capacity to sorb $\mathrm{P}$ in comparison to other Western Australian soils.

2. The build up of leachable $P$ in sandy soils due to fertilization with superphosphate and coastal superphosphate can be monitored by measuring an acid-extractable fraction.

3. The short term potential for $P$ loss can be estimated by measuring water-soluble soil solution $\mathrm{P}$ before the wet season begins.

4. An estimate of the time required to decrease $P$ concentrations to the minimum required for plant growth could be made from laboratory simulations of potential annual losses of $\mathrm{P}$ and bicarbonate extractable $P$. This estimate would require field calibration in order to be used predictively.

5. Phosphorus losses by leaching can be decreased by applying fertilizers containing less water-soluble $\mathrm{P}$, less frequently.

There are no quick agricultural solutions to decreasing $\mathrm{P}$ losses from deep grey sands under pastures which contain $\mathrm{P}$ in excess of plant requirements. However, there are long term strategies, such as soil testing, rational fertiliser use and alternative farming systems which would be mutually beneficial to both farmers and the general community who wish to use the recreational facilities of an estuarine system and its catchment. These long term strategies are also appropriate for other soils to ensure that excess $\mathrm{P}$ is not lost from them.

\section{Acknowledgments}

The authors wish to thank T. Cremin for the preparation of Fig. 2.

\section{References}

1. Allen DG and Jeffery RC (1990) Methods for analysis of phosphorus in Western Australian soils. Report of Investigation No 37, Agricultural Chemistry Laboratory, Chemistry Centre of Western Australia, Perth

2. Birch PB (1982) Phosphorus export from coastal plain drainage to the Peel-Harvey estuarine system, Western Australia. Aust J Mar Freshwater Res 33: 23-32

3. Colwell JD (1963) The estimation of phosphorus fertilizer requirements of wheat in southern New South Wales by soil analysis. Aust J Exp Agric Anim Husb 3: 190-197

4. Hodgkin EP, Black RE and Birch PB (1984) Progress of the Peel-Harvey Estuary studies. Western Australian Department of Conservation and Environment, Special Interim Report, August 1984

5. Kinhill Engineers (1988) Peel Inlet and Harvey Estuary Management Strategy. Environmental Review and Management Programme - Stage 2

6. Ritchie GSP, Weaver DM and Deeley DM (1984) Factors affecting phosphorus losses from sandy soils. Western Australian Department of Conservation and Environment Bulletin No. 160, pp 59-69

7. Ritchie GSP, Weaver DM and Anderson GC (1985) Long term phosphorus losses from deep grey sands and duplex soils. Western Australian Department of Conservation and Environment Bulletin No. 195, pp 45-57

8. Weaver DM, Ritchie GSP, Anderson GC and Deeley DM (1988a) Phosphorus leaching in sandy soils. I. Short term effects of fertilizer applications and environmental conditions. Aust J Soil Res 26: 177-190

9. Weaver DM, Ritchie GSP and Anderson GC (1988b) Phosphorus leaching in sandy soils. II. Laboratory studies of the long term effects of the phosphorus source. Aust J Soil Res 26: 191-200

10. Yeates JS, Deeley DM, Clarle MF and Allen D (1984) Modifying fertilizer practices. J Agric West Aust 25: 87-91 